About the Author

Charles I. Nagy Jr. is assistant professor of political science at Corpus Christi State University. He is author of Political Parties and System Flexibility (1980).

\section{Access to the National Archives}

Bartholomew H. Sparrow

University of Chicago

The condition of the National Archives concerns all political scientists." Many political scientists use Archival records for research on American government or on international relations. The National Archives currently holds 800,000 cubic feet of federal records in its main building, and stores another 500,000 cubic feet of records in other buildings in the Washington, D.C. area. These records constitute a rich resource for understanding political history, developing hypotheses and testing theories.

\section{For the National Archives,}

as the eventual sepository

of valuable federal records,

problem compounds

Those who do not themselves use the Archives are indirectly affected by the ideas and findings of those who do. This is the multiplier effect: the research done by a few political scientists, social scientists and historians cumulatively informs the work of other academics, as well as government officials, journalists and the public at large.

Finally, the Archives has preeminent status as a cultural and political institution. The research done by social scientists, historians, biographers, genealogists, journalists, lawyers, educators, employees from other Federal agencies at the National Archives interprets and defines American government and society. Such research makes possible the establishment of detailed and differentiated history. But the records at the National Archives and those of the Presidential Libraries (both under the aegis of the National Archives and Records Administration) also disclose the operation of liberal democratic government. The Archives constitute a unique resource for this exploration.

\section{Because declassification}

\section{procedures necessitate}

approval by each ageney

fasticipating in the

creation of a document,

requests for declassifica.

tion under the freedom

$\frac{\text { of Information Act may }}{\text { take of to two years. }}$

I had three separate occasions over the last two years to conduct research at the National Archives. My surprise at the lack of access to records from the 1940s and at the lack of knowledge of the existence or whereabouts of other documents prompted me to inquire into the situation at the National Archives. These remarks summarize my brief investigation.

Many of the military records I wanted to see were still classified-even where the preponderance of records were over forty years old. Ten thousand cubic feet of Navy Department records alone remain classified, and over 300,000,000 pages overall await declassification at the 
National Archives. The Presidential libraries hold another 19 million pages of classified material. It is not that all these records are vital to national security; rather, there are simply not the resources for securing their release.

\section{... every four months \\ the federal government \\ generates additional}

recosds equal in amount

to those froduced in the

124 years between George Woodrow Wilson.

The declassification bottleneck is part of a more general problem of the classification of records throughout the Federal government.' President Nixon's Executive Order 11654 established systematic declassification for records for most documents over thirty years old. President Carter reduced the period for declassification for most documents to twenty years, but added the caveat that each agency issue its own guidelines for reviewing records. Under President Reagan's Executive Order 12356, each federal agency has to approve the records to be classified. EO 12356 also omitted a timetable for declassification.2 Not surprisingly, the amount of material declassified dropped radically. ${ }^{3}$ Federal agencies now have every incentive to refuse declassification when in doubt. There are over a trillion pages of classified documents, and about 40 percent of all records received currently by the Archives are classified. Under EO 12356, both the embarrassing and the militarily critical are treated alike. The foxes run the chicken coop.

For the National Archives, as the eventual repository of valuable federal records, the declassification problem compounds existing handicaps. The budget cutbacks of 1981 and 1982, which reduced Archival staff by 26 percent, have yet to be restored. NARA staff and budgets have only risen incrementally since then, from $\$ 79$ million appropriated in 1982 to $\$ 121.9$ million in FY 1989.4 In 1987, the National Archives still had only one-half the declassification staff it had in 1980. Of the 58 employees engaged in declassification in fiscal 1989, eight were assigned to State Department records, six worked on A.I.D. records, and ten reviewed records in the Presidential Libraries. Fifteen engaged in general systematic declassification.

Yet because Freedom of Information Act (FOIA) requests have priority, the actual number of employees working on systematic declassification is far fewer. That is, those engaged on general declassification have to be pulled off for FOIA requests; at any one time, far fewer than 15 work on general systematic declassification-perhaps as few as three. Just as seriously, there is about a 50 percent attrition rate for Archives employees declassifying records. The security clearance necessary for declassification takes over a year to obtain, but once employees get clearance, other governmental jobs open up-many more appealing than the characteristically tedious job of screening government records. ${ }^{5}$

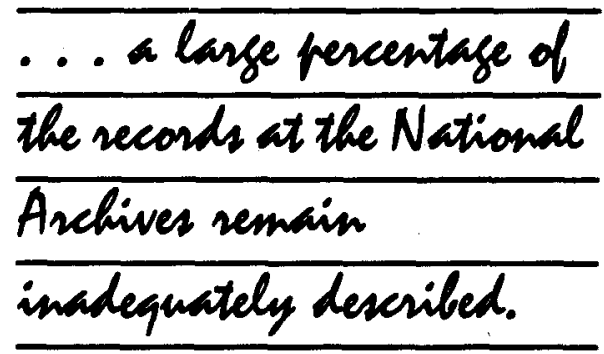

At present, declassification absorbs only $1 \%$ of the NARA's budget, 6 and FOIA requests absorb much of this: handling FOIA requests costs about $\$ 18$ a page, in comparison to 56 cents a page for systematic review. Yet with the attrition in the declassification staff and the priority acceded FOIA requests, there is little that 
can be done in the short term. As a result of these constraints, additional funding and personnel for declassification can only be stop-gap measures. Because declassification procedures necessitate approval by each agency participating in the creation of a document, requests for declassification under the Freedom of Information Act may take up to two years. ${ }^{7}$

\section{The National Archives is}

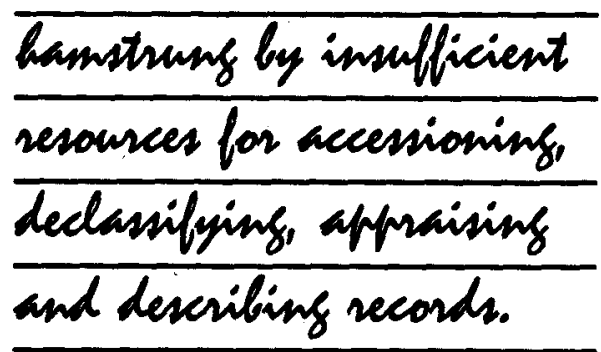

Meanwhile the volume of government records increases at a geometric rate. Unlike the presidential libraries, the Archives continually receive new materials-about 3 percent of the records produced by all three branches of the federal government. The Archives currently hold the equivalent of a 230-mile-long shelf of records, and every four months the federal government generates additional records equal in amount to those produced in the 124 years between George Washington and Woodrow Wilson. The Archives are swamped, and the NARA's budget is not keeping up.

Besides the declassification backlog and the budgetary squeeze, the Archives faces problems of severely limited space, inadequate finding aids, and poor employee morale. I had first-hand experience of the inadequacy of many of the inventories and record-descriptions. Dissatisfaction by Archival employees-for the most part highly knowledgeable and dedicated employees -was also evident. Many received little recognition for their efforts and were chronically overworked.

The National Archives, under U.S. Archivist Don W. Wilson, is taking measures to confront some of these problems. The first priority is the construction of a 1.7 million square foot new archives building on the University of Maryland campus in College Park.8 "Archives II" will allow records currently housed throughout Washington (mostly in the 1934 National Archives building on Pennsylvania Avenue and the National Record Center in Suitland, Maryland) to be stored in one place. The new building will also allow for new facilities, computer areas, and-not trivially-a first-rate cafeteria. Moving into Archives II should help staff morale.

Other measures initiated by the Archives for countering the above problems include enhanced and on-going training for all levels, from Archivist technicians to administrators. ${ }^{9}$ By offering more training and promotional opportunities, the Archives will provide incentives so as to improve and retain qualified staff. Another response by the Archives is (1) to increase coordination between the federal bureaus creating records with the National Ar. chives, their eventual repository, and (2) to manage electronic records so as to guarantee their preservation and accessibility. This "life-cycle" management addresses the creation, categorization, and commensurability of records. ${ }^{10}$ It is critical, especially with the burgeoning use of electronic records.

\section{Records that cannot be}

\section{used may as well not}

\section{exist; inaccessible,}

\section{undescribed, and unneces-}

\section{sarily classified reconds}

serve little purpose.

Nonetheless, significant challenges still exist. The problems with declassification remain. Their resolution demands a new Executive Order so that all but sensitive materials become automatically declassified at the end of thirty calendar years. As the NCC puts it, "[t]he burden of proof and the administration for extending the classification of documents" has to be on the originating agency. " A longer-term 
solution might be legislation amending the National Archives and Records Administration Act so as to give the Archives enhanced authority over records in its custody.

\section{A comsmitment to the}

\section{promotion of access to \\ Archival records is eritical.}

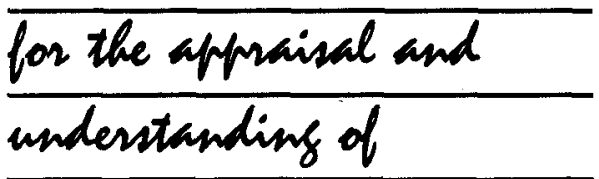

\section{American democracy.}

Furthermore, a large percentage of the records at the National Archives remain inadequately described. ${ }^{12}$ This was often my experience for Navy, Social Security, and Labor Department records: descriptions of records were brief and frequently misleading. In one sense, this is part of archival research: seeing what there is to see. It is not to be expected that a fortyyear-old filing system coincide with a researcher's own categories or with filing systems of the present. Given, then, the limits of even the best (and necessarily dated) finding aids, the researcher needs knowledgeable personnel able to guide the researchers through large record collections, interpret finding aids, and engage in intellectual exchange. Such detailed knowledge of complex record groups can only come with extensive personal experience. Although the National Archives is exploring ways to enhance subject and reference specialization, 13 such specialization of Archival personnel runs counter to training programs and promotional systems now in effect. Without a larger staff and a strong financial commitment, this problem will persist.

Even the construction of a new archives building creates problems of its own. Transferring 700,000 cubic feet of records (some records will remain at the downtown Archives building, as will genealogical records) will involve unprecedented logistics. It will also necessitate the withholding of records, including some heavily used record groups, for months at a time. On the budgetary side, the planning and staffing of the move to Archives II will absorb annual NARA resources up to the scheduled transfer in 1994-\$6 million, for example, was budgeted in fiscal 1989. In addition, the financing of Archives II through issuing long-term bonds means that after 1994, the National Archives will have to budget an additional $\$ 20$ million, approximately, for interest payments.

Last, the Archives has recently acquired extensive and complex records, such as from the Congressional investigation of the Iran-Contra affair, the records of the AIDS Commission, sections of the "U.S. Army Vietnam" records (some 4000 cubic feet) and the files of special prosecutors. The staff and budget of the Archives has no extra provision for these new responsibilities. ${ }^{14}$ The National Archives is hamstrung by insufficient resources for accessioning, declassifying, appraising and describing records. Where Canada spends approximately $\$ 2.14$ per capita (Canadian dollars) on their national archives, the U.S. spends only 50 e per capita at the federal level. ${ }^{15}$ Any increased funding has, of course, to come from Congress. ${ }^{16}$

Dr. Page Putnam Miller of the National Coordinating Committee addressed these and other problems in her extremely useful report, "Developing a Premier National Institution."17/ would simply like to underscore one of her main points: that in order to secure additional funding, the National Archives needs a clear exposition of its purpose. ${ }^{18}$ Archivist Wilson proposed ten goals in March of 1988. They are worth examining. His goals are (1) the building of Archives II; (2) increasing computerization and developing reference tools in machine-readable forms; (3) making a commitment to records access; (4) maintaining the Archives as a repository for all Federal records; (5) improving conservation; (6) expanding outreach efforts to the general public; (7) encouraging greater staff creativity; (8) keeping a quality Archival staff; (9) balancing research use and the protection of records; and (10) assuming a leadership role in national col- 
lection policy. ${ }^{19}$ Note, however, that neither in this list nor in his introductory comments in the 1988 Annual Report was there a voiced common theme. The constant in both was the priority of building "Archives II."

I would suggest that common to all these goals is the status of the $\mathrm{Na}$ tional Archives as a service organization. This theme implicitly runs through the National Archives's 1988 Annual Report and Archivist Don Wilson's two addresses; it is explicit in the National Coordinating Committee report. The National Archives's preservation, storage, description and accessing of permanently valuable records of the Federal government is all with the end of immediate, near term or eventual public use. Records that cannot be used may as well not exist; inaccessible, undescribed, and unnecessarily classified records serve little purpose.

While Archivist Wilson is surely correct to work for greater national prominence for the Archives and for enhanced recognition of the National Archives's field organizations, ${ }^{20}$ । would suggest that scholarly access in particular is of principal importance. Scholars, far more than genealogists or legal researchers, for instance, do the "documenting of our national heritage."

More importantly, it is primarily political scientists, other social scientists and historians who need the records of the National Archives in order to explore, detail, and comment on the operation of the Federal Government. A commitment to the promotion of access to Archival records is critical for the appraisal and understanding of American democracy. The construction of an extensive new facility, important as it is, is but one step in this service.

\section{Notes}

*I would like to thank Page Putnam Miller, Director of the National Coordinating Committee for the Promotion of History (NCC) and jill D. Brett, Public Affairs Officer of the National Archives and Record Administration, for their generous assistance and cooperation. I am also indebted to the others at the National Archives who assisted me.

I. The "Resolution on Declassification Pol- icy" of April 3, 1987, issued by the Policy Board of the NCC, gave evidence of the seriousness of the classification problem:

- The Stilwell Commission, established by the Department of Defense, concluded in its 1986 report Keeping the Nation's Secrets that "Too much information appears to be classified and much at higher levels than is warranted."

- In 1986 the information Security Over. sight Office recommended to the $\mathrm{Na}$ tional Security Council that steps be taken to reduce unnecessary classification and to increase the professionalism and accountability of security personnel.

- The House Permanent Select Committee on Intelligence in a February 4, 1987 report calls for the reduction of classified information, noting that overclassification "damages the credibility of appropriately classified information."

2. EO 12356 also set up the Information Security Oversight Office, which oversees the security of records produced by over $70 \mathrm{de}$ partments, individual agencies and offices of the Executive branch.

3. According to the "Briefing Sheet of December 8, 1988," of the NCC: "in the 1970s, the number of pages reviewed for declassification consistently exceeded 30 million, reaching 52 million in 1975 and 90 million in 1980; but in the 1980s the totals have dropped to 11 million and 13 million. Likewise, the numbers of pages declassified by the State Department for comparable projects decreased approximately sevenfold following the implementation of the Reagan Executive Order.'

4. The National Archives appropriation for FY 1990 is $\$ 126.6$ million. The National Archives and Records Administration was not an independent agency until 1985. Before then, the NARA was part of the General Services Administration.

5. Because some records may be "bulk" declassified, requests for declassification may be handled quickly for the individual researcher: my request for approximately 25 linear feet of the Navy's Bureau of Aeronautics records (not under the $F O \mid A$ ) took less than two weeks to process. For more sensitive records, this procedure would, of course, not work.

6. The National Archives and Record Administration. Annual Report for the Year Ended September 30, 1988. Washington, D.C., p. 89, Appendix " $C$." After next year, the Archives will be working on a computerized system available to the public for-tracking FOIA requests.

7. Ninety percent of FOIA requests are for documents over 30 years old. FOIA requests 
are also unsatisfactory for much research: historians may not know what records they need on a subject. The researcher accordingly needs comprehensive access to records, and cannot select specific documents for an FOIA request in advance ("NCC Briefing Sheet-December 8. 1988').

8. "Archives II" will be located on a 37-acre plot on the edge of a golf course. The architects are Hellmuth, Obata \& Kassabaum; the engineers are Ellerbe Becket. 1988 estimates for the cost of Archives II came to $\$ 206$ million.

9. "Remarks of Don W. Wilson, Archivist of the United States to the Staff of the National Archives March 31, 1988, Third Anniversary of Independence": "Walter Rundell Lecture" given by Don W. Wilson, Archivist of the United States, April 27, 1989.

10. My experience did not involve electronic records, but with the advent of electronic storage and retrieval systems, NARA and the Office of Management and Budget are aware of the problems attendant with such new technology. Indeed, in his address of March 31, 1988, U.S. Archivist Wilson listed computational concerns and machine readable records as his third chief concern. An Electronic Records Conference was convened and submitted recommendations to the President's Council on Management Improvement.

II. "Talking Points for Initial Efforts Toward Strengthening Declassification Policy," June 13, 1989. National Coordinating Committee.

12. Don W. Wilson, Walter Rundell Lecture, April 27, 1989. The NCC estimates that about one-third of the records are insufficiently described. "NCC Briefing Sheet-March 16, 1989."

13. "Remarks of Don W. Wilson," March $31,1989$.

14. "NCC Briefing Sheet-March 16, 1989," National Coordinating Committee.

15. "NCC Briefing Sheet-March 16, 1989," National Coordinating Committee. The American system does have its advantages. NARA allows researchers up to 21 boxes of records at one point of time and are open from 8:45 to 10:00 PM. Copies may be done by the re-

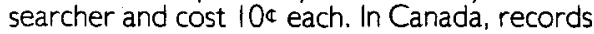
cost 20c, and have to be copied by staff, thus causing a week to ten-day wait for small orders, and a four- to six-week delay for larger orders. In Great Britain, records cost about 60٪ per page to reproduce; building hours are only 9:30 to 5:00 PM. Monday through Friday. On the other hand, the finding aids are computerized and the records are quickly available.

16. The pertinent Congressional committees are the House and Senate Appropriations Subcommittees on Treasury, Postal Service and General Government.
17. "Developing a Premier National Institution: A Report From the User Community to the National Archives, " by Page Putnam Miller, Director of the National Coordinating Committee for the Promotion of History. (Single copies of the report are available free by writing: Page Putnam Miller, NCC, 400 A St., S.E., Washington, D.C. 20003. Additional copies or bulk orders are $55 ₫$ per copy.)

To their credit, officials at the Archives have acknowledged the value of Dr. Miller's frank and frequently critical assessment of the operation and administration of the National Archives. The National Coordinating Committee is a consortium of over fifty historical, archival, political, library, and genealogical organizations (including the APSA).

18. "Developing a Premier Research Institution," pp. 5, 36.

19. "Remarks of Don W. Wilson," March 31, 1988."

20. Don W. Wilson, Walter Rundell Lecture, April 27, 1989; National Archives and Record Administration 1988, Annual Report, p. 3.

\section{Continuities in Political Research: Evidence from the APSR Since the 1960s*}

\author{
Samuel C. Patterson \\ Jessica R. Adolino \\ Kevin T. McGuire \\ Ohio State University
}

Since the American Political Science Review began publication in November 1906, its managing editor has reported annually to the council of the Association. These annual reports provide a valuable basis for understanding and recounting the development of the Review as a scholarly and scientific journal (see Patterson, Ripley, and Trish 1988). It is helpful to assess the performance of the Review in any one year by conducting both diachronic and comparative analyses of the ways in which the journal reflects, and perhaps influences, the etiology of political research.

In this analysis, we combine an evaluation of the performance of the APSR during 